\title{
開大する骨盤環骨折の治療の検討
}

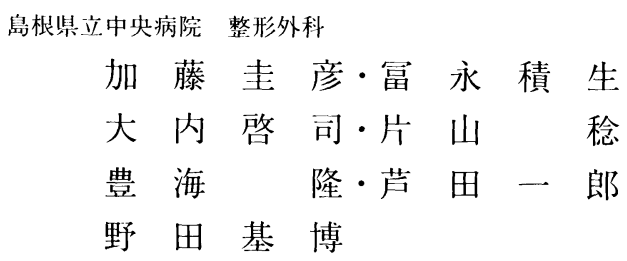

\section{A Study of Treatment of Pelvic Ring Disruptions}

by

Yoshihiko Katoh, Sekio Tominaga, Keiji ohuchi, Minoru Katayama, Takashi Toyoumi. Ichiroh Ashida and Motohiro Noda

Department of Orthopedic Surgery, Shimane Prefectural Central Hospital

From 1981 to 1989,126 cases of pelvic fractures were treated in our hospital. We divided them accord ing to the classification of pelvic fractures offered by Trunkey and evaluated 11 unstable cases which be longed to Type I. II - A and II -C. The patients' age, sex, type of trauma, associated bone injuries, com plications, treatment and clinical results were reviewed. Of 11 cases, only one case of Type I revealed the limitation of range of motion. Ten cases were asymptomatic and clinical results were satisfactory.

\section{は じめに}

骨盤骨折は強力な外力が作用して発生することが多 く全身に与える影響が大きい，特に肖盤環が破綻し， 開大傾向を示す症例は安定性の獲得につとめなければ ならないが，合併症を有するものも多くしばしば治療 に難啮する．今回我々は骨盤環の開大傾们を示す症例 を retrospectiveに調査し検討したので報告する.

\section{対象及び方法}

昭和 56 年から平成元年までの關に骨盤骨折により 当科入院治療を行った 126 例のうち Trunkey ${ }^{3)}$ Type I， II-A，II-Cに属する11 例を調查対象とした. Type I は 2 例， II - A 5 例， II - C 2 例であった. 性 別では，男性 8 例，女性 3 例であり，年齢は 17 歳か ら 68 歳，平均 44.5 歳であった。これらについて，受 傷機転，合併骨傷，合俇症，治療法，治潦成績を調查 した。

\section{結果}

受傷機転では交通事故が 6 例で最多であった．合併 骨傷は total 16 力所, 平均 1.5 力所であった。今回認 められた合併症は表 1 のごとくであり，全身管理の重 要性を增す原因となった観血的治療を行った症例は, Type I 1 例, Type II-C 2 例であり, 残り 8 例に対し ては保存的治療を行った。

\section{症例}

症例 $1: 22$ 歳 女性.

現病歴：昭和 63 年 9 月 15 日, 自殺目的に高さ約 $10 \mathrm{~m}$ の岩場より飛び降り受傷し, 直ちに救急車にて 搬送され，当科を受㟝した。

来院時所見：顔面挫創，骨盤部，汹滕部腫脹，左:足 部挫滅創等を認め, 意識レベルは低下し，最高血生 $60 \mathrm{mmHg}$ とショック状態に宿っていた。

合併症：第 2 腰椎生迫骨折, 活側脛骨高原骨折, 在 Chopart 関節開放性脱F 䯑折 


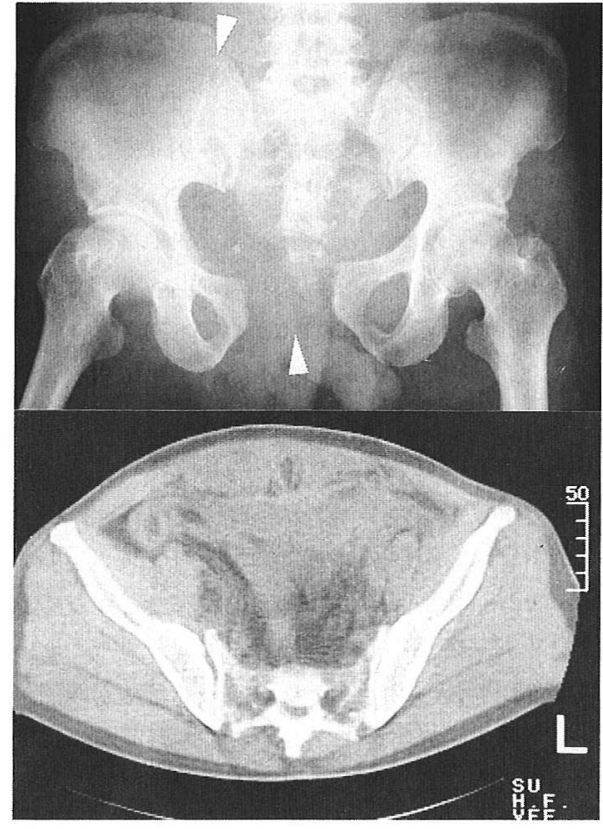

図1 受傷時 Type II-c の骨盤骨折を認める

有片㸝起立

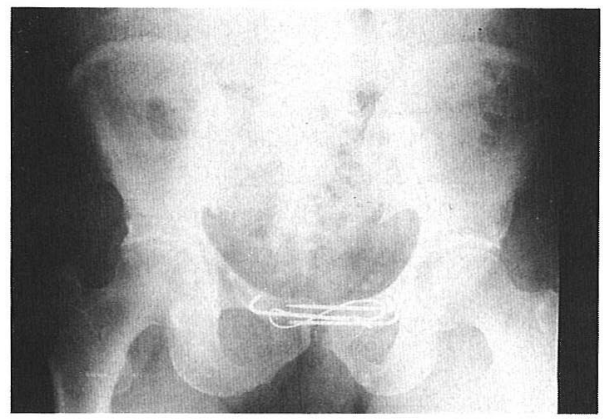

左片朋起立.

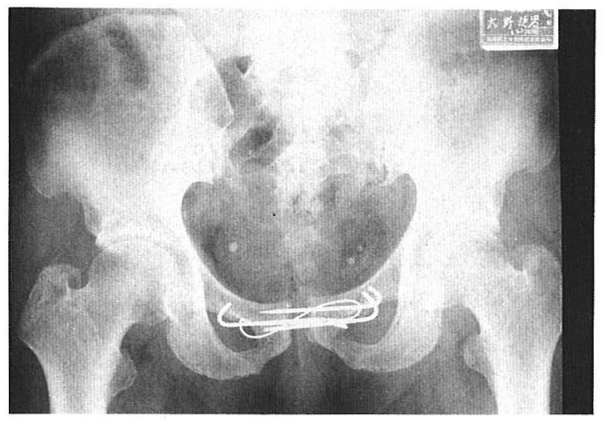

図 2 受傷後 13 力月，左右片脚起立における恥骨結合の ずれは約 $3 \mathrm{~mm}$ である
Type Iの骨盤骨折を認め, 転位傾向を示した。全 身状態の改善を待って受傷後 18 日目に Hoffmannの 創外固定を行った. 術後 3 力月で創外固定を除去, 術 後 8 力月, 骨盤環の安定性が得られている. 術後 1 年 8 力月の現在, 可動域制限, 疼痛, 跛行を認めない.

症例 $2: 16$ 歳 男性

現病歴：昭和 60 年 8 月 30 日, オートバイで走行中, 対向車線に飛び出し対向車と衝突, 転倒し受傷した。 直ちに救急車にて搬送され，当科を受㟝した。頭部外 傷のため, 同日脳外科入院となったが, 症状が改善し たため，9月 2 日当科に転科となった。

来院時所見 : 胸腰部痛, 骨盤及び右足部の腫脹, 疼 痛, 会陰部裂傷を誌め, 意識しベルは低下し, 不穏状 態であった。

合併症：第 1.3 腰椎左横突起骨折, 右距骨骨折, 右踵骨骨折，頭蓋骨骨折，左腎損傷，会陰部裂傷

Type II - Aの骨盤骨折を認めたため，左下腿より， 直達率引を行い, 保存的治療を行った。受傷後 2 力月 で隺引を除去し, 以後徐々にリハビリテーションを 行った，受傷後 12 カ月の時点で可動域制限, 疼痛, 跛行を䜑めない。

症例 $3: 60$ 歳 男性

現病歴：平成元年 1 月 11 日，オートバイで走行中, 交差点で自動車と接触し転倒, 受傷した。直ちに近医 に搬送されたが，外傷性くも膜下出血，硬膜外血腫が 認められたため，当院を紹介され受爕した，意識しべ ルの低下はあるものの, 特に脳外科的に手術適応はな く，当科に入院となった.

来院時所見：頸部，右手関節部，恥骨結合部の腫脤 及び疼痛，右上肢の池緩性麻痺が認められた。

合併症：第 7 頸椎骨折，右暁骨末端骨折，右腕神経 㩘損傷, 外傷性くも膜下出血监, 急性硬膜外血腫, 出血 性潰瘍

Type II - Cの骨盤骨折を認めキャンパス率引による 保存的治療を行った（図 1 ). 入院後出血性潰㳑を併 発し発熱も継続したため, 全身状態の改善を待って受 傷後 54 日目に䎵骨結合固垁術を行った。受傷後 13 力 月，左右片㑢起立において䎵骨結合部のずれは約 3 $\mathrm{mm}$, 股関節運動制限, 管静時及び運動侍痛等まった く認めない（図 2).

\section{考察}

骨盤骨折は受傷原因が強力な外力によるものが多 


\begin{tabular}{|c|c|}
\hline \multicolumn{2}{|l|}{ 頍部 } \\
\hline 外傷性くも膜下出血 & 2 \\
\hline 急性硬膜外血腫 & 1 \\
\hline 㵋蓋省筒折 & 2 \\
\hline \multicolumn{2}{|l|}{ 胸部 } \\
\hline 血気胸 & 1 \\
\hline \multicolumn{2}{|l|}{ 腹部 } \\
\hline 出血性潰瘍 & 3 \\
\hline 膀胱破裂 & 1 \\
\hline 腎損傷 & 1 \\
\hline \multicolumn{2}{|l|}{ その他 } \\
\hline 腕神経丵損傷 & 2 \\
\hline
\end{tabular}

く, 合併骨傷や, 他の主要臓器に合併損傷を伴ってい る場合も少なくない，従って, 初䜌時ショック状態を 呈することも多く，まず全身状態の管理を行い，続い て治療の優先順位を決定し, これに従って治療を進め ることが必要となる ${ }^{2)}$ 。このため, 整形外科的治療が 制約を受けたり, 遅延する場合もある，近年，骨盤骨 折に対して観血的治療が積極的に行われるようになっ てきたが，その利点とともに，手術による侵襲や，出 血, 感染の危険性等の欠点も十分に考虑しなければな らない ${ }^{1)}$. 特に, 骨盤環骨折は重症例が多く, 手術適 応は骨折型とともに全身状態等を考慮して慎重に決定 すべきである，我々は，Type I 及び Type II - C のう ち保存的治療で安定性の得られないものに対して, 観 血的治療を行うと言う治療方針をとってきた．全身状 態が墨く精神状態が不安定で観血的治療を行い得な かった Type I の 1 例に股関節の可動域制限を認めた が, その他に股関節可動域制限, 疼痛, 跛行を認めた
症例は無く, 満足のいく治療成績を得ている.

\section{まと め}

1）昭和 56 年から平成元年までの間に経験した骨 盤骨折 126 例のうち, Trunkey 分類 Type I, II - A, II-Cに属する 11 例について検討を加えた.

2) Type I は 2 例， II - A 5 例， II - C 4 例であり， うち 3 例（I 1 例，II-C 2 例）に対しては観血的治 療を行い，他の 8 例に対しては保存的治療を行った。

3）保存的治療を行った Type Iの 1 例に股関節の 可動域制限を認めたが，他の 10 例においては股関節 可動域制限, 疼痛, 跛行を認めた症例は無く, 満足の いく治療成績を得た.

4）骨盤環骨折には合併損傷を伴うことが多く，他 科との協力が必要であり，チーム医潦が要求される。

5）治療方針の決定に際しては，骨折型だけで無く 全身状態や合併損傷を考慮した総合的判断が必要であ る.

\section{参 考 文 献}

1) Connoly, J.F. et al. : Closed treatment of pelvic and lower extremity fractures. Clin. Orthop. $240: 115-128$, 1989.

2) Mucha, P. et al, : Analysis of pelvic fracture management. J. Trauma $24: 379-386,1984$.

3) Trunkey, D.D. et al. : Management of pelvic fractures in blunt trauma injury. J. Trauma $14: 912-923,1974$. 